UDC 519.6

\title{
AN EXACT FINITE ELEMENT SCHEME OF THE BOUNDARY VALUE PROBLEM FOR AN ORDINARY DIFFERENTIAL EQUATION
}

\author{
V. Verbitskyi ${ }^{1}$, A. Loktev ${ }^{2}$ \\ Odessa, I. I. Mechnikov National University, \\ Dvoryanskaya str., 2, Odessa, 65082, \\ e-mail: ${ }^{1}$ v.verbitskyi@onu.edu.ua, ${ }^{2}$ anton.loktev@stud.onu.edu.ua
}

\begin{abstract}
A scheme of the finite element method for solving a boundary value problem on a finite interval for an ordinary differential equation of the second order is proposed. The differential equation contains a nonnegative piecewise constant coefficient of the unknown function. For the boundary value problem, the corresponding continuous and finite-dimensional variational problems are constructed. Since the bilinear form of these problems is continuous and positive definite, the variational problems are uniquely solvable. Basic functions of a finite-dimensional subspace of a finite-dimensional variational problem are constructed using solutions of the Dirichlet problem for the corresponding homogeneous differential equation on a finite element. If all the points of discontinuity of the coefficient of a differential equation are contained among the mesh nodes, such solutions are easy to construct, because the differential equation will have constant coefficients on a finite element. Trial and test functions of the finite element method are selected from one finite-dimensional subspace. The matrix of the finite element approximation of the boundary value problem is tridiagonal symmetric and positive definite. The scheme is exact in the sense that the finite element and exact solutions coincide at the mesh nodes. The result can be regarded as an illustration of the phenomenon of superconvergence of the finite element method, which consists in the fact that in a given area there can be points for which the difference between the exact and finite element solutions (or their derivatives) converges to zero faster than some norm of the difference of these solutions. As an example, it is shown that the proposed scheme of the finite element method allows one to construct an analytical solution to a boundary value problem on a finite interval for an ordinary differential equation with constant coefficients if the solution of the Dirichlet problem for the corresponding homogeneous differential equation is known.
\end{abstract}

Key words: finite element method, superconvergence, exact finite element scheme.

\section{INTRODUCTION}

The research on superconvergence for finite element methods has been conducted extensively by many researchers over the last four decades. This phenomenon was first addressed in [17], and the term "superconvergence" was first used in [11]. Since then, superconvergence has become to be an active research topic in finite element methods for partial differential equations; see [1,2,6-10,12-14,19-21] and the references cited therein for an incomplete list of publications.

The phenomenon of superconvergence is that in the considerated region there can be points $x_{i}$ for which the difference $u\left(x_{i}\right)-u_{h}\left(x_{i}\right)$ of exact $u(x)$ and finite element $u_{h}(x)$ solutions (or $\left.\nabla u\left(x_{i}\right)-\nabla u_{h}\left(x_{i}\right)\right)$ tends to zero faster than norm of this difference.

At the same time, of great interest are cases where at some points the equality of the approximate and exact solutions is observed. For example, the finite element solution of the Dirichlet problem for the equation $-u^{\prime \prime}=f$ constructed using continuous linear splines coincides at the grid nodes with the values of the exact solution. If we use cubic

(C) Verbitskyi V., Loktev A., 2020 
Verbitskyi V., Loktev A.

ISSN 2078-5097. Вісн. Львів. ун-ту. Сер. прикл. матем. та інф. 2020. Вип. 28

basic splines, then this phenomenon is no longer observed. On the contrary, it is possible to change not the space of finite elements, but the equation. For example, for the onedimensional Helmholtz equation, the indicated values can differ quite significantly [5]. The so-called generalized FEM (or GFEM) was proposed in $[3,4,15]$, the idea of which is to take into account the structure of a particular equation when constructing a finitedimensional space. Regarding superconvergence for this method, some fairly general results were obtained in [2], where a theoretical study of the inhomogeneous Neumann problem for the Poisson equation in the two-dimensional domain is given, and the results are illustrated by numerical experiments on the one-dimensional problem. In [18] for one class of the generalized finite element method it is proved that the approximate solution of the boundary value problem for an ordinary differential equation is coincided with the exact solution at the grid nodes. In the proposed finite element scheme the spaces of test and verification functions are different.

We proposed to choose test and verification functions from one finite-dimensional space. For a boundary value problem with piecewise constant coefficients, the existence of a finite element solution and its coincidence at the grid nodes with an exact solution is proved.

\section{Finite-element approximation of a boundary value PROBLEM}

Let's consider the Dirichlet problem,

$$
\begin{gathered}
L u \equiv-u^{\prime \prime}+q(x) u=f, \quad x \in(0,1), \\
u(0)=u(1)=0,
\end{gathered}
$$

where $f \in L^{2}(0 ; 1), q(x) \geq 0$ is a piecewise constant function. The weak form for the problem (1) seeks $u \in H_{0}^{1}(0 ; 1)$ such that

$$
a(u, v) \equiv \int_{0}^{1}\left[u^{\prime} v^{\prime}+q(x) u v\right] d x=\int_{0}^{1} f v d x \quad \forall v \in H_{0}^{1}(0 ; 1) .
$$

On the interval $(0 ; 1)$ we define a grid $\omega_{h}$ with nodes

$$
0=x_{0}<x_{1}<\cdots<x_{n-1}<x_{n}=1 .
$$

We assume that among the grid nodes there are all discontinuity points of the function $q(x)$. On the interval $\left(x_{i-1} ; x_{i}\right)(i=\overline{1, n})$ we consider boundary value problems

$$
\begin{aligned}
& L \varphi_{i}^{(1)}(x)=0, \quad \varphi_{i}^{(1)}\left(x_{i-1}\right)=1, \quad \varphi_{i}^{(1)}\left(x_{i}\right)=0, \\
& L \varphi_{i}^{(2)}(x)=0, \quad \varphi_{i}^{(2)}\left(x_{i-1}\right)=0, \quad \varphi_{i}^{(2)}\left(x_{i}\right)=1 .
\end{aligned}
$$

Since the function $q(x)$ is a constant on the interval $\left(x_{i-1} ; x_{i}\right)$, it is easy to find solutions of problems $(3),(4)$ :

$$
\varphi_{i}^{(1)}(x)=\frac{\operatorname{sh}\left(k_{i}\left(x_{i}-x\right)\right)}{\operatorname{sh}\left(k_{i} h_{i}\right)}, \quad \varphi_{i}^{(2)}(x)=\frac{\operatorname{sh}\left(k_{i}\left(x-x_{i-1}\right)\right)}{\operatorname{sh}\left(k_{i} h_{i}\right)},
$$

where $q(x) \equiv k_{i}^{2}$ on $\left(x_{i-1}, x_{i}\right), h_{i}=x_{i}-x_{i-1}$ and $\operatorname{sh}(x)=\left(e^{x}-e^{-x}\right) / 2$ is hyperbolic sinus. 
With the node $x_{i}$ we associate a continuous function

$$
\varphi_{i}(x)=\left\{\begin{array}{l}
\varphi_{i}^{(2)}(x), \quad x \in\left(x_{i-1} ; x_{i}\right), \\
\varphi_{i+1}^{(1)}(x), \quad x \in\left(x_{i} ; x_{i+1}\right), \\
0, \quad x \in(0 ; 1) \backslash\left(x_{i-1} ; x_{i+1}\right) .
\end{array}\right.
$$

We define a finite-dimensional subspace $V_{h} \subset H_{0}^{1}(0 ; 1)$ with basis $\left\{\varphi_{i}(x)\right\}_{i=1}^{n-1}$. With variational problem (2) we associate a finite-dimensional variational problem which searches for a function $u_{h} \in V_{h}$ such that

$$
a\left(u_{h}, v_{h}\right)=\int_{0}^{1} f v_{h} d x \quad \forall v_{h} \in V_{h}
$$

Since the bilinear form $a(\cdot, \cdot)$ is continuous on $H_{0}^{1}(0 ; 1)$ and $H_{0}^{1}(0 ; 1)$-elliptical, it follows from the Lax-Milgram lemma (see, for example, [16, p. 536]) that problems (2) and (5) are uniquely solvable.

The solution of problem (5) will be sought in the form

$$
u_{h}(x)=\sum_{i=1}^{n-1} \alpha_{i} \varphi_{i}(x)
$$

where $\alpha_{i}=u_{h}\left(x_{i}\right)$. Then problem (5) is a system of linear algebraic equations (SLAE) with unknowns $\alpha_{i}$ :

$$
\sum_{i=1}^{n-1} \alpha_{i} a\left(\varphi_{i}, \varphi_{j}\right)=\int_{0}^{1} f \varphi_{j}(x) d x, \quad j=\overline{1, n-1}
$$

Performing integration by parts and taking into account (3) and (4), we obtain

$$
\begin{gathered}
\sum_{i=1}^{n-1} \alpha_{i} a\left(\varphi_{i}, \varphi_{j}\right)= \\
=\alpha_{j-1} a\left(\varphi_{j-1}, \varphi_{j}\right)+\alpha_{j} a\left(\varphi_{j}, \varphi_{j}\right)+\alpha_{j+1} a\left(\varphi_{j+1}, \varphi_{j}\right)= \\
=\alpha_{j-1} \int_{x_{j}}^{x_{j-1}} \varphi_{j}^{(1)^{\prime}}(x) \varphi_{j}^{(2)^{\prime}}(x)+q(x) \varphi_{j}^{(1)}(x) \varphi_{j}^{(2)}(x) d x+ \\
+\alpha_{j}\left\{\int_{x_{j-1}}^{x_{j}} \varphi_{j}^{(2)^{\prime}}(x) \varphi_{j}^{(2)^{\prime}}(x)+q(x) \varphi_{j}^{(2)}(x) \varphi_{j}^{(2)}(x) d x+\right. \\
\left.+\int_{x_{j}}^{x_{j+1}} \varphi_{j+1}^{(1)^{\prime}}(x) \varphi_{j+1}^{(1)^{\prime}}(x)+q(x) \varphi_{j+1}^{(1)}(x) \varphi_{j+1}^{(1)}(x) d x\right\}+ \\
+\alpha_{j+1} \int_{x_{j}}^{x_{j+1}} \varphi_{j+1}^{(2)^{\prime}}(x) \varphi_{j+1}^{(1)^{\prime}}(x)+q(x) \varphi_{j+1}^{(2)}(x) \varphi_{j+1}^{(1)}(x) d x= \\
+\alpha_{j}\left\{\left.\varphi_{j}^{(2)}(x) \varphi_{j}^{(2)^{\prime}}(x)\right|_{x_{j-1}} ^{x_{j}}+\left.\varphi_{j+1}^{(1)}(x) \varphi_{j+1}^{(1)^{\prime}}(x)\right|_{x_{j}} ^{x_{j+1}}\right\}+ \\
+\left.\left.\alpha_{j+1} \varphi_{j+1}^{(2)}(x) \varphi_{j+1}^{(1)^{\prime}}(x)\right|_{x_{j}} ^{x_{j+1}}(x) \varphi_{j}^{(2)^{\prime}}(x)\right|_{x_{j-1}} ^{x_{j}}+
\end{gathered}
$$


Verbitskyi V., Loktev A.

Thus, SLAE (6) takes the form:

$$
\begin{gathered}
\frac{-k_{j}}{\operatorname{sh}\left(k_{j} h_{j}\right)} \alpha_{j-1}+\left\{\frac{k_{j} \operatorname{ch}\left(k_{j} h_{j}\right)}{\operatorname{sh}\left(k_{j} h_{j}\right)}+\frac{k_{j+1} \operatorname{ch}\left(k_{j+1} h_{j+1}\right)}{\operatorname{sh}\left(k_{j+1} h_{j+1}\right)}\right\} \alpha_{j}+ \\
+\frac{-k_{j+1}}{\operatorname{sh}\left(k_{j+1} h_{j+1}\right)} \alpha_{j+1}=f_{j}, \quad j=\overline{1, n-1},
\end{gathered}
$$

where $\alpha_{0}=\alpha_{n}=0, f_{j}=\int_{x_{j-1}}^{x_{j+1}} f \varphi_{j}(x) d x$.

Theorem 1. The finite element solution $u_{h}(x)$ coincides with the solution $u(x)$ of problem (2) at the nodes of the grid $\omega_{h}$.

Proof. Note that $u_{h}\left(x_{0}\right)=u\left(x_{0}\right)=0, u_{h}\left(x_{n}\right)=u\left(x_{n}\right)=0$ by the construction of the finite element scheme. It follows from (2) and (5) that

$$
a\left(u-u_{h}, \varphi_{j}\right)=0, \quad j=\overline{1, n-1} .
$$

Integrating by parts, we obtain

$$
\begin{gathered}
a\left(u-u_{h}, \varphi_{j}\right)=\int_{x_{j-1}}^{x_{j}}\left(u(x)-u_{h}(x)\right)^{\prime} \varphi_{j}^{(2)^{\prime}}(x)+q(x)\left(u(x)-u_{h}(x)\right)^{\prime} \varphi_{j}^{(2)^{\prime}}(x) d x+ \\
+\int_{x_{j}}^{x_{j+1}}\left(u(x)-u_{h}(x)\right) \varphi_{j+1}^{(1)^{\prime}}(x)+q(x)\left(u(x)-u_{h}(x)\right)^{\prime} \varphi_{j+1}^{(1)^{\prime}}(x) d x= \\
=\left.\left(u(x)-u_{h}(x)\right) \varphi_{j}^{(2)^{\prime}}(x)\right|_{x_{j-1}} ^{x_{j}}+\left.\left(u(x)-u_{h}(x)\right) \varphi_{j+1}^{(1)^{\prime}}(x)\right|_{x_{j}} ^{x_{j+1}}= \\
=-\left(u\left(x_{j-1}\right)-u_{h}\left(x_{j-1}\right)\right) \varphi_{j}^{(2)^{\prime}}\left(x_{j-1}\right)+ \\
+\left(u\left(x_{j}\right)-u_{h}\left(x_{j}\right)\right)\left(\varphi_{j}^{(2)^{\prime}}\left(x_{j}\right)-\varphi_{j+1}^{(1)^{\prime}}\left(x_{j}\right)\right)+ \\
+\left(u\left(x_{j+1}\right)-u_{h}\left(x_{j+1}\right)\right) \varphi_{j+1}^{(1)^{\prime}}\left(x_{j+1}\right)= \\
=\frac{-k_{j}}{s h\left(k_{j} h_{j}\right)}\left(u\left(x_{j-1}\right)-u_{h}\left(x_{j-1}\right)\right)+ \\
+\left\{\frac{k_{j} \operatorname{ch}\left(k_{j} h_{j}\right)}{\operatorname{sh}\left(k_{j} h_{j}\right)}+\frac{k_{j+1} \operatorname{ch}\left(k_{j+1} h_{j+1}\right)}{s h\left(k_{j+1} h_{j+1}\right)}\right\}\left(u\left(x_{j}\right)-u_{h}\left(x_{j}\right)\right)+ \\
+\frac{-k_{j+1}}{\operatorname{sh}\left(k_{j+1} h_{j+1}\right)}\left(u\left(x_{j+1}\right)-u_{h}\left(x_{j+1}\right)\right) .
\end{gathered}
$$

Therefore, system (8) is homogeneous SLAE with the matrix of system (6). Thus, system (8) has the unique trivial solution $u\left(x_{j}\right)-u_{h}\left(x_{j}\right)=0(j=\overline{1, n-1})$.

\section{EXAMPLE}

Let's consider the boundary value problem,

$$
\begin{gathered}
-u^{\prime \prime}(x)+k^{2} u(x)=f(x), \quad x \in(0 ; 1), \\
u(0)=u(1)=0,
\end{gathered}
$$

where $f(x) \in L^{2}(0 ; 1)$. If $f(x) \equiv 1$, then the solution of the boundary value problem is the function

$$
u(x)=\frac{\left(e^{-k}-1\right) e^{k x}+\left(1-e^{k}\right) e^{-k x}+e^{k}-e^{-k}}{k^{2}\left(e^{k}-e^{-k}\right)} .
$$

We solve problem (9) by the finite element method using the grid $\omega_{h}=\{0, x, 1\}$, where $x$ is an arbitrary point in the interval $(0 ; 1)$. Then

$$
u_{h}(t)=\alpha_{1} \varphi_{1}(t),
$$


where

$$
\varphi_{1}(t)=\left\{\begin{array}{l}
\frac{s h(k t)}{s h(k x)}, \quad t \in(0 ; x), \\
\frac{s h(k-k t)}{\operatorname{sh}(k-k x)}, \quad t \in(x ; 1),
\end{array}\right.
$$

and the coefficient $\alpha_{1}$ is determined from the equation

$$
\alpha_{1} a_{11}=f_{1}
$$

where, according to (7),

$$
\begin{gathered}
a_{11}=\frac{k \operatorname{ch}(k x)}{s h(k x)}+\frac{k \operatorname{ch}(k-k x)}{\operatorname{sh}(k-k x)} \\
f_{1}=\int_{0}^{x} f(t) \frac{\operatorname{sh}(k t)}{\operatorname{sh}(k x)} d t+\int_{x}^{1} f(t) \frac{\operatorname{sh}(k-k t)}{\operatorname{sh}(k-k x)} d t .
\end{gathered}
$$

Moreover, $\alpha_{1}=f_{1} / a_{11}$ is the value of the exact solution of the boundary value problem at an arbitrary point $x$. Thus, we have established the formula for calculating the exact solution of the boundary value problem (9):

$$
u(x)=\frac{f_{1}}{a_{11}} .
$$

Indeed, it is easy to verify that if $f(x) \equiv 1$, then

$$
f_{1}=\frac{\operatorname{ch}(k x)-1}{k \operatorname{sh}(k x)}+\frac{\operatorname{ch}(k-k x)-1}{k \operatorname{sh}(k-k x)},
$$

and solution (11) coincides with (10).

\section{CONCLUSion}

A scheme of the finite element method for solving a boundary value problem for an ordinary differential equation with piecewise constant coefficients is proposed. The basic functions of finite-dimensional subspaces are constructed using solutions of the Dirichlet problem for a homogeneous differential equation on a finite element. Those solutions are easy to construct if all the points of discontinuity of the equation coefficients are contained among the grid nodes. The scheme is exact in the sense that the finite element solution coincides with the exact solution at the nodes of the grid used to construct the finite element subspace. The result can be considered as an illustration of the phenomenon of superconvergence of the finite element method.

\section{REFERENCES}

1. Asadzadeh $M$. Asymptotic error expansions for the finite element method for second order elliptic problems in $R^{n}(n \geq 2)$, I: Local interior expansions / M. Asadzadeh, A. Schatz, W. Wendland //SIAM J. Numer. Anal. - 2010. - Vol. 48. - P. 2000-2017.

2. BabuskaI. Superconvergence in the generalized finite element method: Techn. Rep. 0545 / I. Babuska, U. Bauerjee, J.E. Osborn.- Austin, Texas: TICAM, Univ. Texas, 2004.http://www.ices.utexas.edu/research/reports/2005/0545.pdf 
Verbitskyi V., Loktev A.

ISSN 2078-5097. Вісн. Львів. ун-ту. Сер. прикл. матем. та інф. 2020. Вип. 28

3. Babuska I. Special finite element methods for a class of second order elliptic problems with rough coefficients / I. Babuska, G. Caloz, J. Osborn // SIAM J. Numer. Analys. - 1994.Vol. 31 (4). - P. 945-981.

4. Babuska I. The partition of unity finite element method / I. Babuska, J. M. Melenk // Int. J. Numer. Meth. Engng. - 1997.- Vol. 40 (4). - P. 727-758.

5. BabuskaI. Is the pollution effect of the FEM avoidable for the Helmholtz equation considering high wave numbers? / I. Babuska, S. A. Sauter // SIAM J. Numer. Analys. 1997.Vol. 34 (6).- P. 2392-2423.

6. Brandtz J. H. Superconvergence of tetrahededral quadratic finite elements / J. H. Brandtz, M. Kriezk // J. Comput. Math., 2005. - Vol. 23. - P. 27-36.

7. Cao $W$. Superconvergence of discontinuous Galerkin methods for two-dimensional hyperbolic equations /W.Cao, C.Shu, Y. Yang, Z.Zhang //SIAM J. Numer.Anal.- 2015.Vol. 53 (4).- P. 1651-1671.

8. Cao $W$. Is $2 \mathrm{~K}$-conjecture valid for finite volume methods? /W. Cao, Z. Zhang, Q. Zou // SIAM J. Numer.Anal. - 2015. - Vol. 53 (2). - P. 942-962.

9. Chen $C$. The highest order superconvergence for bi- $k$ degree rectangular elements at nodes - a proof of $2 k$-conjecture / C. Chen, S. Hu // Math. Comp. - 2013. - Vol. 82 - P. 1337-1355.

10. Chen $H$. An interior estimate of superconvergence for finite element solutions for secondorder elliptic problems on quasi-uniform meshes by local projections / H. Chen, J. Wang // SIAM J. Numer.Anal. - 2003. - Vol. 41 (4). - P. 1318-1338.

11. Douglas J. Superconvergence for Galerkin methods for the two-point boundary problem via local projections / J. Douglas, T. Dupont // Numer. Math. - 1973.- Vol. 21. - P. 270-278.

12. Ewing R. E. Superconvergence of the velocity along the Gauss lines in mixed finite element methods / R. E. Ewing, R. D. Lazarov, J. Wang // SIAM J. Numer. Anal. - 1991.- Vol. 28.P. 1015-1029.

13. Huang $Y$. Superconvergence of quadratic finite elements on mildly structured grids / Y. Huang, J. Xu // Math. Comp. 2008. - Vol. 77 (263). - P. 1253-1268.

14. Krizek $M$. Superconvergence phenomenon on three-dimensional meshes / M. Krizek // International Journal of Numerical Analysis and Modeling. - 2005. - Vol. 2 (1). - P. 43-56.

15. Melenk J.M. The partition of unity finite element method: Basic theory and applications / J. M. Melenk, I. Babuska // Comput. Meth. Appl. Mech. Engng. - 1996. - Vol. 139. - P. 289314.

16. Oden J. T. Applied Functional Analysis. Third edition / J. T. Oden, L. F. Demkowicz.- CRC Press, 2018.

17. Oganesjan L. A. An investigation of the rate of convergence of variational difference schemes for second order elliptic equations in a two-dimensional region with smooth boundary. / L. A. Oganesjanand, L. A. Ruhovec // Z. Vycisl. Mat. i Mat. Fiz. - 1969. - Vol. 9. - P. 11021120. (in Russian).

18. Panin A.A. On the problem of superconvergence of finite elements method/A. A. Panin // Comput. Math. Math. Phys. - 2008. - Vol.48(12).- P. 2211-2216. (in Russian).

19. SchatzA.H. Superconvergence in finite element methods and meshes that are symmetric with respect to a point / A. H. Schatz, I. H. Sloan, L. B. Wahlbin // SIAM J. Numer. Anal.1996. - Vol. 33. - P. 505-521.

20. Wang C. Superconvergence of Ritz-Galerkin finite element approximations for second order elliptic problems / C. Wang // Numer. Meth. for Partial Differential Equations.- 2018.Vol. 34, № 3. - P. 838-856.

21. Zienkiewicz O.C. The superconvergence patch recovery and a posteriori error estimates, Part 2, Error estimates and adaptivity / O. C. Zienkiewicz, J. Z. Zhu // Internat. J. Numer. Methods Engrg. - 1992.- Vol. 33. - P. 1365-1382.

Article: received 16.07 .2020

revised 21.09.2020

printing adoption 23.09.2020 
Verbitskyi V., Loktev A.

\title{
ТОЧНА СКІНЧЕННО-ЕЛЕМЕНТНА АПРОКСИМАЦІЯ КРАЙОВОЇ ЗАДАЧІ ДЛЯ ЗВИЧАЙНОГО ДИФЕРЕНЦІАЛЬНОГО РІВНЯННЯ
}

\author{
В. Вербіцький ${ }^{1}$, А. Локтєв ${ }^{2}$ \\ Одесъкий начіональний університет імені I. I. Мечникова, \\ вул. Дворянсъка, 2, Одеса, 65082, \\ e-mail: ${ }^{1}$ v.verbitskyi@onu.edu.ua, ${ }^{2}$ anton.loktev@stud.onu.edu.ua
}

\begin{abstract}
Запропоновано схему методу скінченних елементів розв'язання крайової задачі на скінченному проміжку для звичайного диференціального рівняння другого порядку. Диференціальне рівняння містить невід'ємний кусково-постійний коефіцієнт у невідомій функції. Для крайової задачі побудовано відповідні неперервна та скінченновимірна варіаційні задачі. Оскільки білінійна форма цих задач $є$ неперервною та додатно визначеною, то варіаційні задачі однозначно розв'язні. Базисні функції скінченновимірного підпростору скінченновимірної варіаційної задачі будуються 3 використанням рішень задачі Діріхле для відповідного однорідного диференціального рівняння на скінченному елементі. Якщо серед вузлів сітки містяться всі точки розриву коефіцієнта диференціального рівняння, то такі рішення легко побудувати, бо на скінченному елементі диференціальне рівняння матиме постійні коефіцієнти. Пробні та перевірочні функції методу скінченних елементів вибирають з одного скінченновимірного підпростору. Матриця скінченно-елеметної апроксимації крайової задачі є тридіагональною симетричною та додатно визначеною. Схема точна в тому сенсі, що скінченно-елементний і точний розв'язки збігаються в вузлах сітки. Результат можна розглядати як ілюстрацію явища суперзбіності методу скінченних елементів, яке полягає в тому, що в цій області можуть знайтися точки, для яких різниця точного і скінченно-елементного розв'язків, (або їхніх похідних) збігаються до нуля швидше, ніж деяка норма різниці цих рішень. Як приклад наведено, що запропонована схема методу скінченних елементів дає змогу побудувати аналітичний розв'язок крайової задачі на скінченному проміжку для звичайного диференціального рівняння з постійними коефіцієнтами, якщо відомо рішення задачі Діріхле для відповідного однорідного диференціального рівняння.
\end{abstract}

Ключові слова: метод скінченних елементів, суперзбіжність, точна скінченно-елементна схема. 